\title{
Deregulation of E-cadherin, $\beta$-catenin, APC and Caveolin-1 expression occurs in canine prostate cancer and metastatic processes
}

\author{
Priscila E. Kobayashi ${ }^{a}$, Carlos E. Fonseca-Alves ${ }^{\mathrm{a}}$, Luis G. Rivera-Calderón ${ }^{\mathrm{b}}$, Márcio Carvalho ${ }^{\mathrm{a}}$, \\ Hellen Kuasne ${ }^{\mathrm{c}}$, Silvia R. Rogatto ${ }^{\mathrm{d}}$, Renée Laufer-Amorim ${ }^{\mathrm{a}, *}$
}

a São Paulo State University (UNESP), Department of Veterinary Clinic, School of Veterinary Medicine and Animal Science, Botucatu, SP, Brazil

${ }^{\mathrm{b}}$ São Paulo State University (UNESP), Department of Veterinary Pathology, School of Agricultural and Veterinarian Sciences, Jaboticabal, SP, Brazil

${ }^{\mathrm{c}}$ International Center for Research (CIPE), AC Camargo Hospital, Liberdade, São Paulo, Brazil

${ }^{\mathrm{d}}$ Department of Clinical Genetics, Vejle Hospital and Institute of Regional Health, University of Southern Denmark, Denmark

\section{A R T I C L E I N F O}

\section{Keywords:}

Dog

WNT pathway

Prostatic carcinoma

Oncology

Metastasis

\begin{abstract}
A B S T R A C T
Prostate cancer is a heterogeneous disease with high levels of clinical and gene heterogeneity, consequently offering several targets for therapy. Dogs with naturally occurring prostate cancer are useful models for molecular investigations and studying new treatment efficacy. Three genes and proteins associated with the WNT pathway ( $\beta$-catenin, APC and E-cadherin) and Caveolin-1 (CAV-1) were evaluated in canine pre-neoplastic proliferative inflammatory atrophy (PIA), prostate cancer and metastatic disease. The APC gene methylation status was also investigated. As in human prostate cancer, cytoplasmic and nuclear $\beta$-catenin, which are fundamental for activating the canonical WNT pathway, were found in canine prostate cancer and metastasis. Membranous E-cadherin was also lost in these lesions, allowing cellular migration to the stroma and nuclear localization of $\beta$-catenin. In contrast to human prostate tumours, no APC downregulation or hypermethylation was found in canine prostate cancer. The $C A V-1$ gene and protein overexpression were found in canine prostate cancer, and as in humans, the highest levels were found in Gleason scores $\geq 8$. In conclusion, as with human prostate cancer, $\beta$-catenin and E-cadherin in the WNT pathway, as well as Caveolin-1, are molecular drivers in canine prostate cancer. These findings provide additional evidence that dogs are useful models for studying new therapeutic targets in prostate cancer.
\end{abstract}

\section{Introduction}

Human prostate cancer is a common malignancy worldwide, and its metastasis causes nearly all prostate cancer-related mortalities (Siegel et al., 2017). High levels of clinical and molecular heterogeneity also frequently occur (Ciccarese et al., 2017). The Cancer Genome Atlas Research Network (2015) reported seven prostate cancer (PC) subtypes including gene fusions (ERG, ETV1/4 and FLI1), recurrent SPOP, FOXA1 and IDH1 mutations, activated PI3K/Akt/mTOR and MAPK pathway mutations ( $\sim 25 \%$ of localized PC) and germ line or somatic DNA repair genes mutations (including BRCA1/2, CDK12, ATM, FANCD2 and RAD51C) ( $\sim 20 \%$ of primary PC) (Cancer Genome Atlas Research Network, 2015). These data revealed several therapeutic targets that require detailed investigations. Although animal models have been successfully used to evaluate the efficacy of new cancer treatments, animals with spontaneous cancer who share the same environment as humans are more reliable in cancer studies (Galuschka et al., 2017;
Ittmann et al., 2013).

Dogs spontaneously develop PC and share the same environment with humans. In addition to their similarities to human PC and metastasis development, dogs can develop pre-neoplastic lesions, a condition known as prostatic inflammatory atrophy (PIA) (Toledo et al., 2010). Furthermore, clinical and histopathological similarities to human PC have been described, making dogs an interesting model for molecular investigations (LeRoy and Northrup, 2009); however, few molecular studies on canine PC have been reported (Fonseca Alves et al., 2017; Kobayashi et al., 2017; Rivera-Calderón et al., 2016; Fonseca-Alves et al., 2013).

The WNT/ $\beta$-catenin canonical pathway has been well studied in embryogenesis and pathogenesis, including in human PC (Poniah et al., 2017; Seo et al., 2017; Zhang et al., 2017), but poorly explored in canine PC. WNT proteins are glycoproteins with important roles in embryonic development and tissue homeostasis (Kypta and Waxman, 2012) and are generally inactivated in normal prostate cells

\footnotetext{
*Corresponding author at: São Paulo State University - UNESP, Department of Veterinary Clinic, School of Veterinary Medicine and Animal Science, Veterinary Teaching HospitalFMVZ UNESP, 18618-970, Brazil.

E-mail address: renee@fmvz.unesp.br (R. Laufer-Amorim).
} 
(Valkenburg et al., 2014).

Canonical WNT pathway regulation involves the $\beta$-catenin destruction complex, and $\beta$-catenin is the primary nuclear mediator that activates target genes (Li et al., 2012; Yu et al., 2009). When no WNT signal is received, the destruction complex (APC and other proteins) degrades cytoplasmic $\beta$-catenin, preventing it from localizing to the nucleus (Stamos and Weis, 2013; Yu et al., 2009).

$\beta$-catenin exists in the cell membrane, nucleus and cytoplasm and is involved in cellular adhesion and signal transduction. $\beta$-catenin protein levels and locations can be controlled by E-cadherin (Chen et al., 2004). E-cadherin is a transmembrane cellular adhesion molecule that is essential for maintaining normal tissue morphology and epithelial differentiation (Jaggi et al., 2005). WNT signaling can induce the Snail family (E-cadherin suppressors), consequently downregulating E-cadherin expression (Cervantes-Arias et al., 2013). Loss of E-cadherin is associated with the epithelial-mesenchymal transition, a reversible change in cell phenotype, allowing cell migration and invasiveness (Kypta and Waxman, 2012; Jaggi et al., 2005). The membrane E-cadherin/ $\beta$-catenin complex is essential for epithelial cell adhesion and is also important for prostate gland formation and function (Kypta and Waxman, 2012). If no E-cadherin is expressed in the cell membrane, $\beta$ catenin dissociates and translocates to the cytoplasm/nucleus. These events are associated with tumour invasion and metastasis in both dogs and humans (Lean et al., 2014; Schmalhofer et al., 2009).

The adenomatous polyposis coli (APC) gene encodes a tumour suppressor that is mutated in some human colorectal cancers and hypermethylated in some high Gleason score prostate cancers (Bjerke et al., 2014; Richiardi et al., 2013). Absence of the APC protein induces $\beta$-catenin to accumulate in the cytoplasm and translocate to the nuclei, activating cell proliferation (Fonseca-Alves et al., 2015; Lean et al., 2014). APC can shuttle between the nucleus and cytoplasm and export $\beta$-catenin from the nucleus (Henderson, 2000).

Caveolin-1 (CAV-1) plays important roles in carcinogenesis by regulating cell proliferation, and its roles differ among distinct histological tumour types (Fu et al., 2017). In human PC, increased CAV-1 expression is associated with poor prognosis and high biochemical recurrence risk (Mathieu et al., 2016). Upregulating CAV-1 promotes hormone resistance via lipid synthesis in castration-resistant prostate cancer (Karantanos et al., 2016).

Based on the Wnt/ß-catenin pathway's relevance and the importance of CAV-1 in human PC development and malignant progression, canines with normal prostates, PIA, PC or prostate metastasis were selected to investigate these molecules' involvement in canine prostatic lesions.

\section{Materials and methods}

\subsection{Patients}

Forty-eight prostatic tissues (11 normal prostate, 11 PIA and 26 PC) and four PC metastases were obtained from the Veterinary Pathology Service, School of Veterinary Medicine and Animal Science, São Paulo State University (UNESP), Botucatu, SP, Brazil. The prostate samples were collected from animals at necropsy, 1 hour post-mortem $(n=41)$ or by incisional biopsies $(n=7)$. Normal tissues were obtained from necropsies of animals with no prostatic disease history. Normal prostates were macroscopically evaluated after making parallel serial cuts. Ten fragments were collected, and no histopathological alterations were found in the 5 tissue sections. This study was approved by the Institutional Ethics Committee for the Use of Animals in Research (CEUA) (Protocol\# 107/2015).

Tissue samples used for protein (10 NT, 10 PIA, 10 PC and 4 metastases) and gene expression (11 NT, 11 PIA, 12 PC and 3 metastases) were obtained from formalin-fixed paraffin-embedded (FFPE) tissues (Supplemental Table 1). Histological sections $(3 \mu \mathrm{m})$ of tumour and normal tissues were stained with haematoxylin and eosin (HE).
Histopathology was analysed as per De Marzo et al. (1999) for PIA, and canine PC was classified based on the human WHO classification of Tumors of the Urinary System and Male Genital Organs (Eble et al., 2004), which was recently adapted to canine PC (Palmieri et al., 2014). The Gleason grade score was determined based on Palmieri and Grieco (2015).

APC promoter methylation was analysed using fresh samples (6 NT, 6 PIA and 12 PC) collected at necropsy, immediately frozen by liquid nitrogen immersion, and stored at $-80{ }^{\circ} \mathrm{C}$. Metastasized samples could not be analysed because the samples were archived after being formalin-fixed and paraffin-embedded. Frozen histopathological sections were additionally diagnosed by staining with haematoxylin and eosin (HE) to confirm the initial diagnoses from the methylation analysis.

\subsection{Transcript expression by real-time quantitative PCR (RT-qPCR)}

The areas of interest were marked on the HE slides, and the FFPE tissue blocks were biopsied with a needle (needle $16 \mathrm{G}$ ). The prostate tissue samples were then deparaffinized and protease digested, and the total mRNA was extracted using the RecoverAll ${ }^{\mathrm{TM}}$ Total Nucleic Acid kit (Ambion, Life Technologies, MA, USA) per the manufacturer's recommendations.

The RNA concentration (NanoDrop ${ }^{\mathrm{TM}}$, ND-8000, Thermo Scientific, MA, USA) and integrity (Bioanalyzer 2100 and Agilent RNA 6000 Nano kit, Agilent Technologies, CA, USA) were assessed in all cases. cDNA was synthesised using $1 \mu \mathrm{g}$ of total RNA treated with DNAse I (Life Technologies, Rockville, MD, USA), $200 \mathrm{U}$ of SuperScript III Reverse Transcriptase enzyme (Life Technologies), $4 \mu \mathrm{L}$ of SuperScript FirstStrand Buffer $5 \times, 1 \mu \mathrm{L}$ of $10 \mathrm{mM}$ dNTP each (Life Technologies), $1 \mu \mathrm{L}$ of Oligo-(dT) $)_{18}(500 \mathrm{ng} / \mu \mathrm{L})$ (Life Technologies), $1 \mu \mathrm{L}$ of random hexamers (100 ng/ $\mu \mathrm{L}$ ) (Life Technologies), and $1 \mu \mathrm{L}$ of $0.1 \mathrm{M}$ DTT (Life Technologies) in a final volume of $20 \mu \mathrm{L}$. Reverse transcription was performed at $50{ }^{\circ} \mathrm{C}$ for $60 \mathrm{~min}$, then inactivated at $70{ }^{\circ} \mathrm{C}$ for $15 \mathrm{~min}$. cDNA samples were stored at $-80^{\circ} \mathrm{C}$.

RT-qPCR amplification of CTNBB1, APC, CDH1 and $C A V-1$ and the reference genes, GAPH, HPRT, and RPL8 (Supplemental Table 2), was performed using QuantStudio $12 \mathrm{k}$ Flex Thermal Cycler equipment (Applied Biosystems; Foster City, CA, USA). The reactions were performed in triplicate in 384-well plates, using Power SYBR Green PCR Master Mix (Applied Biosystems; Foster City, CA, USA). The most stable reference gene was HTRP, determined by geNorm software (Vandesompele et al., 2002). Relative genes were quantified by the $2^{-\Delta \Delta \mathrm{CT}}$ method (Livak and Schmittgen, 2001).

\subsection{Protein expression by immunohistochemistry (IHC)}

Prostate paraffin sections were placed on charged slides (Starfrost ${ }^{\circledast}$ Knitell, Bielefeld, Germany) and deparaffinized. Sections were stained with primary antibodies against $\beta$-catenin (rabbit polyclonal), APC (rabbit polyclonal), E-cadherin (mouse polyclonal) and Caveolin-1 (rabbit polyclonal). Dilutions, antigen retrieval, and incubation times are detailed in Supplemental Table 3. Endogenous peroxidase activity and non-specific binding were blocked using $8 \%$ hydrogen peroxide in methanol for $20 \mathrm{~min}$ and $8 \%$ skim milk for $60 \mathrm{~min}$, respectively, both at $27^{\circ} \mathrm{C}$. A polymer detection system (Envision ${ }^{\circledR}$, Dako, Carpinteria, United States) was applied as the secondary antibody, and reactions were developed using 3,3'-diaminobenzidine (DAB). Sections were counterstained with Harris haematoxylin (Dinamica, Diadema, Brazil). Positive (normal canine prostate) and negative control samples (Tris buffer instead of the primary antibody) were included for all protein analyses.

ImageJ 1.49v software (National Institutes of Health, USA, http:// imagej.nih.gov/ij/) was used to analyse images for each protein evaluated, which were captured from five different fields $(40 \times$ magnification). Staining was assessed by establishing a "threshold", using ImageJ software as per Da Silva et al. (2017). Then, we established a 
protein expression value by the mean value of the five captured images. For statistical purposes, we compared the prostatic lesions (PIA, PC and metastasis) with the normal prostate sample. Overexpression was considered when the mean expression value of prostatic lesions was higher than the mean of normal samples. Underexpression was considered when the mean expression value of prostatic lesions was lower than the mean of normal samples.

Protein expression was evaluated in epithelial cells from the lesion studied. The stromal signal was excluded manually using "threshold" tool according to Da Silva et al. (2017)

\subsection{DNA extraction and pyrosequencing methylation analysis}

Total DNA was extracted from the frozen prostate tissues using the Qiagen DNeasy ${ }^{\circledast}$ Blood \& Tissue Kit per the manufacturer's protocol. Genomic DNA bisulphite conversion was performed using the EZ DNA Methylation-Gold Kit (Zymo Research Corporation, Irvine, CA, USA).

Primers flanking the promoter region of the $A P C$ gene were designed (Forward: 5' GGGATTAGGTTAGGTAGG 3'; Reverse: 5' [BIOTIN] AATATAACCCACCTACCA $3^{\prime}$; and the sequencing primer 5' GGGATTA GGTTAGGTAGG $3^{\prime}$ ), and the amplicon containing the CpG sites was amplified using PCR (HotStarTaq Master Mix kit, Qiagen). The PCR product was evaluated by pyrosequencing per the manufacturer's instructions (PyroMark ID Q96, Qiagen and Biotage, Uppsala, Sweden). Bisulphite conversion controls in the dispensation order sequence were included in each assay. To ensure efficiency, $100 \%$ and $0 \%$ methylated DNA were also included in each reaction (Zymo Research Corporation).

\subsection{Statistical analysis}

The groups were compared by the CTNBB1, APC, CDH1 and CAV-1 gene expression levels using Kruskal-Wallis or Mann-Whitney $U$ tests. One-way ANOVA was used to compare protein expression in the different lesions, and $t$-tests were used to make comparisons between two groups of lesions and to evaluate the differential methylation among normal tissue, PIA and PC samples. Statistical analyses and graphs were obtained using GraphPad Prism 5.0 (GraphPad Software Inc., La Jolla, CA). $P$-values $<.05$ were considered statistically significant.

\section{Results}

\subsection{Clinical data}

Clinical data were obtained from nine dogs with PC (Table 1). The dogs' mean age $(n=9)$ with PC was 11.3 years (8-16 years). All nine animals were intact males. The most frequent clinical manifestation was haematuria (3/9). One patient (case 24) presented with lameness due to lumbar vertebrae and pelvic metastasis and thus was euthanised.
Table 2

Histological classification data and Gleason scores of samples used in this study.

\begin{tabular}{|c|c|c|}
\hline & $N$ & Gleason score $^{\mathrm{b}}$ \\
\hline \multicolumn{3}{|l|}{ Histological classification } \\
\hline Normal prostate & 11 & \\
\hline PIA $^{\mathrm{a}}$ & 11 & \\
\hline $\mathrm{PC}^{\mathrm{C}}$ & 26 & \\
\hline \multicolumn{3}{|l|}{ Single histological pattern } \\
\hline Cribriform without comedonecrosis & 2 & $4+4=8$ \\
\hline Small acinar/ductal & 3 & $3+3=6$ \\
\hline Tubulo-papillary & 9 & $3+3=6$ \\
\hline \multicolumn{3}{|l|}{ Mixed histological patterns } \\
\hline Cribriform with comedonecrosis, solid & 2 & $5+5=10$ \\
\hline Solid, signet ring, small acinar/ductal & 1 & $5+5=10$ \\
\hline Cribriform with comedonecrosis, solid e signet ring & 1 & $5+5=10$ \\
\hline Cribriform without comedonecrosis, solid & 2 & $4+5=9$ \\
\hline $\begin{array}{l}\text { Cribriform without comedonecrosis, cribriform with } \\
\text { comedonecrosis }\end{array}$ & 2 & $4+5=9$ \\
\hline $\begin{array}{l}\text { Cribriform with comedonecrosis and cribriform without } \\
\text { cribriform }\end{array}$ & 1 & $5+4=9$ \\
\hline Tubulo-papillary, solid & 2 & $3+5=8$ \\
\hline Small acinar/ductal, cribriform & 1 & $3+4=7$ \\
\hline \multicolumn{3}{|l|}{ Metastasis } \\
\hline Cribriform with comedonecrosis & 2 & \\
\hline Tubulo-papillary & 1 & \\
\hline Cribriform with comedonecrosis, small acinar/ductal & 1 & \\
\hline
\end{tabular}

a De Marzo et al. (1999).

b Palmieri and Grieco (2015).

c Palmieri et al. (2014).

\subsection{Histopathological analysis}

Detailed histological classification and Gleason scores of the samples are summarized in Table 2. Twelve of 26 PC samples showed mixed histological patterns, and among these, eight had a cribriform pattern. In the single histological pattern, nine PC samples (9/26) had a tubulopapillary, and three presented a small acinar/ductal pattern $(3 / 26)$. These two tumour subtypes, tubulo-papillary and small acinar/ductal (12 cases), had the lowest Gleason scores. The PC lymph node (case 49) and metastasis in the pelvic area (case 50) presented a cribriform pattern with comedonecrosis (case 24). Case 33 had pulmonary metastasis (case 51) showing a tubulo-papillary pattern. Case 52 (intestinal metastasis) had cribriform with comedonecrosis, including small acinar/ ductal patterned foci. The Gleason grading system revealed four samples with Gleason scores of 10 , followed by scores of $9(n=4 / 26), 8$ $(n=5 / 26), 7(n=1 / 26)$ and $6(n=12 / 26)$.

\subsection{Transcript expression analysis (RT-qPCR)}

No significant differences were observed in the CTNBB1, APC or CDH1 gene expressions among the samples evaluated (Table 3, Fig. 1A, $\mathrm{B}$ and $\mathrm{C}$ ). $C A V-1$ transcription levels were statistically higher in PC samples compared with NT $(p=.017)$ (Table 3, Fig. 1D).

Table 1

Clinical information on the dogs with PC that were used for gene and protein expression analyses $(n=9)$.

\begin{tabular}{|c|c|c|c|c|c|}
\hline Case ID & Race & Age (years) & Clinical symptoms & Surgical treatment & Survival rate \\
\hline 23 & Dachshund & 10 & NA & NA & NA \\
\hline 24 & Mixed breed & 10 & Lameness, urinary incontinence & None & Euthanasia \\
\hline 25 & Pit Bull & 8 & Haematuria, diarrhoea, vomit & Prostatectomy & 3 months \\
\hline 26 & Mixed breed & 10 & Anorexia, tenesmus & Prostatectomy & 2 years \\
\hline 27 & German Shepherd & 13 & Dyschezia, haematuria & NA & NA \\
\hline 28 & Scottish Terrier & 13 & Haematuria & None & NA \\
\hline 29 & Mixed breed & 16 & Anorexia, vomiting & None & Euthanasia \\
\hline 30 & Cocker Spaniel & 10 & Cachexia & None & Euthanasia \\
\hline 31 & Boxer & 12 & NA & NA & NA \\
\hline
\end{tabular}

All cases, except case 31, were neutered. 
Table 3

Median, 25th percentile and 75th percentile for $\beta$-catenin, APC, E-cadherin and Caveolin-1 gene expression in normal, PIA, PC and metastases.

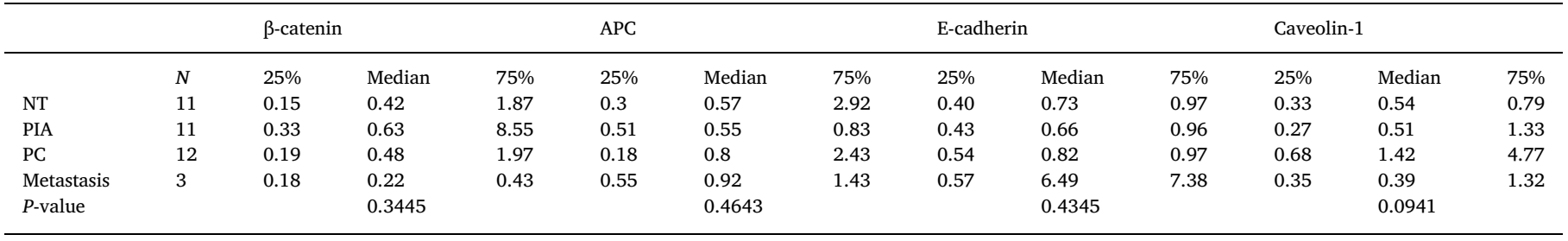

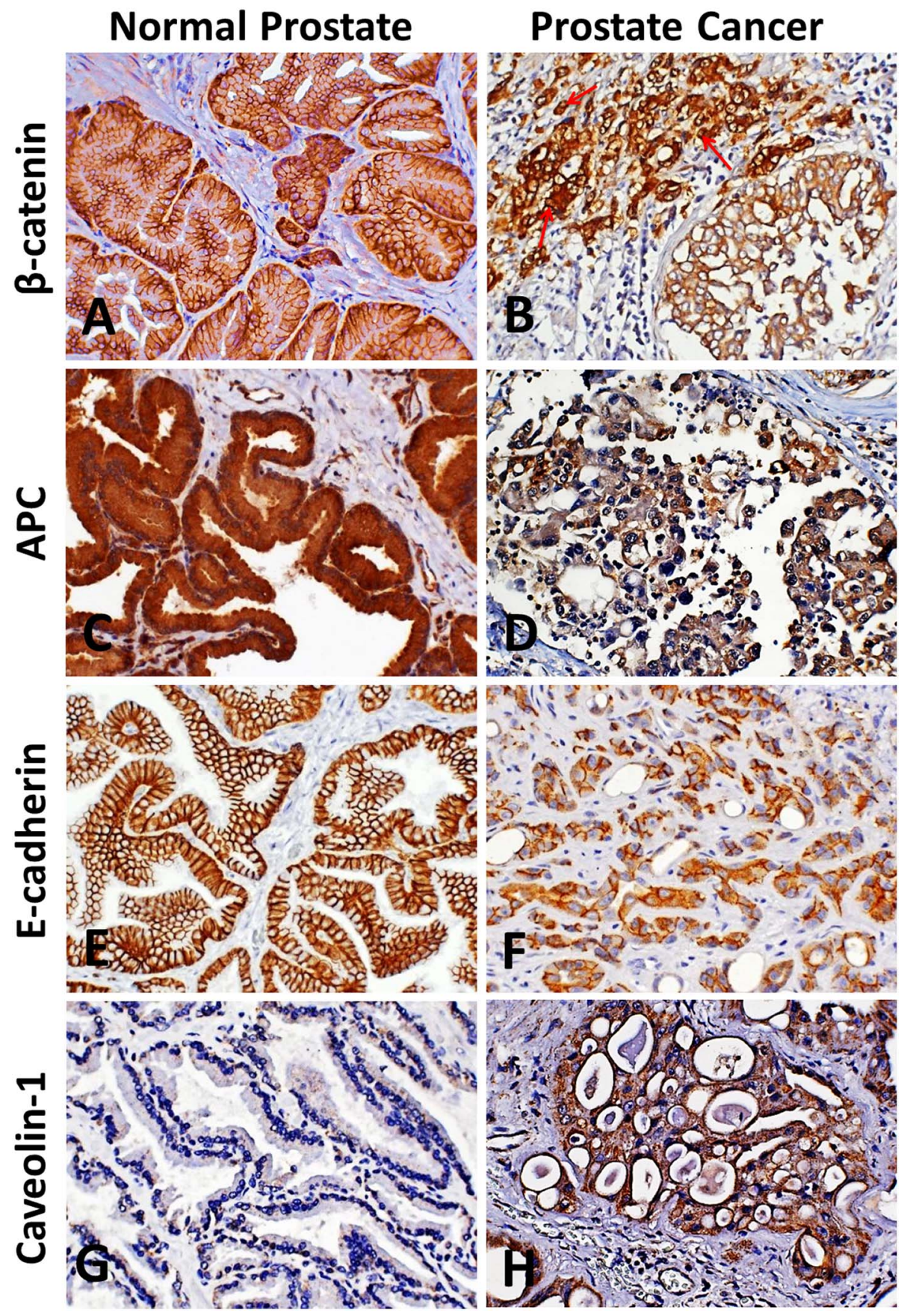

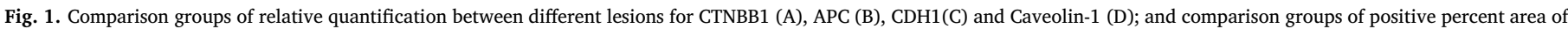
immunohistochemistry between different lesions for $\beta$-catenin (E), APC (F), E-cadherin (G) and Caveolin-1 (H). 

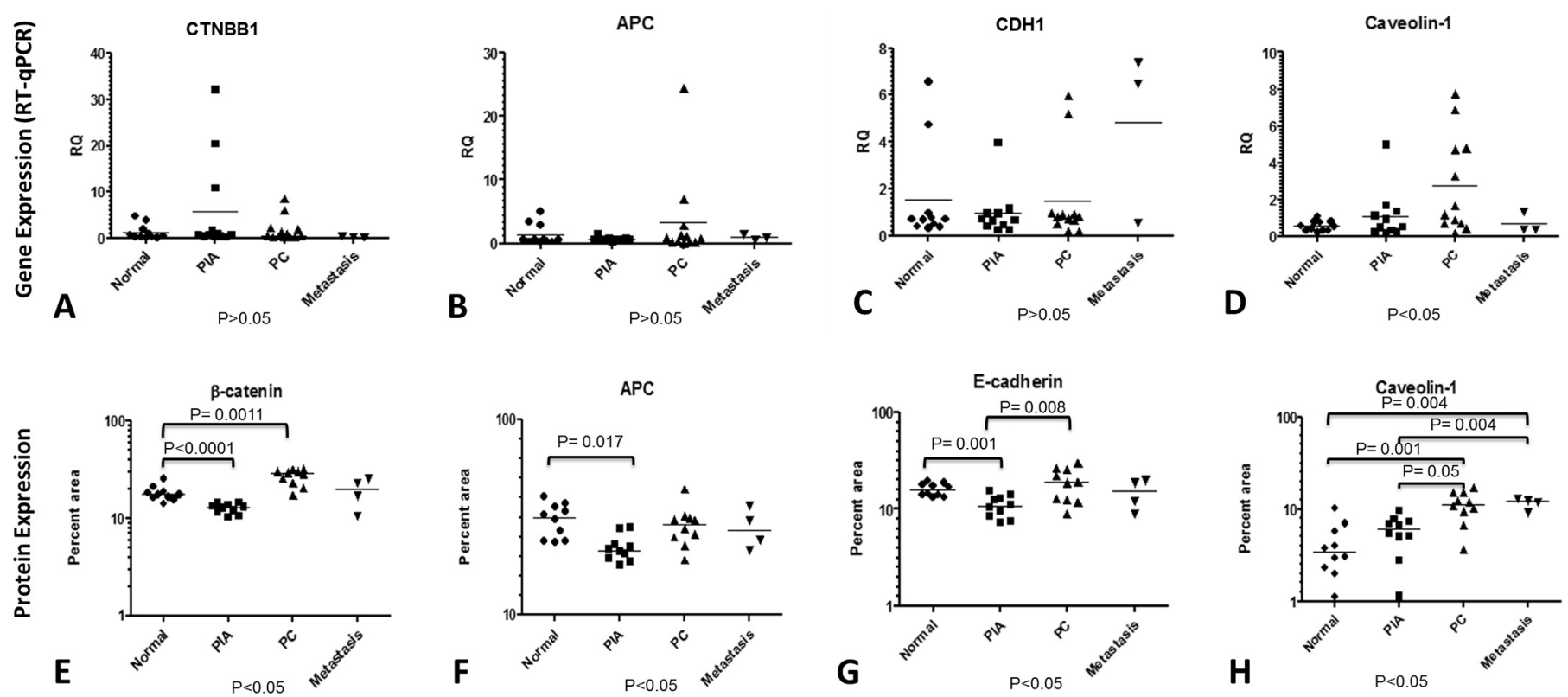

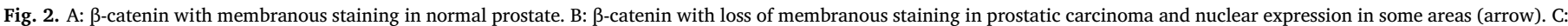

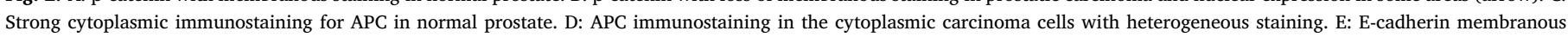

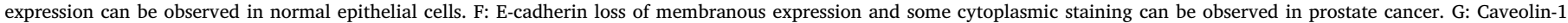
immunostaining in normal prostate. H: Increased Caveolin-1 expression in canine prostate carcinoma.

\subsection{Protein expression analysis (IHC)}

Protein localization based on immunohistochemistry is described in Supplemental Table 4.

B-catenin (Fig. 1E), APC (Fig. 1F), E-cadherin (Fig. 1G) and CAV-1 (Fig. 1H) protein expressions differed significantly $(p<.05)$ among the lesions (PIA, PC and metastases) compared with normal prostatic tissue.

$\beta$-catenin membranous staining was observed in all normal prostate epithelial cells (Fig. 2A). Significant loss of membranous $\beta$-catenin protein expression was found in PIA compared with NT $(p<.05)$. Membranous multifocal loss of $\beta$-catenin was observed in PC tissues (Fig. 2B). Two PC samples and two metastases presented nuclear $\beta$ catenin expression (Fig. 2B). In addition, $\beta$-catenin was overexpressed in PC samples compared with NT $(p<.05)$ due to cytoplasmic immunolocalization in all PC samples (Supplemental Table 4).

APC in normal prostate, PIA and PC samples showed cytoplasmic staining (Fig. 2C) and PC samples showed heterogeneous areas with loss of expression (Fig. 2D). APC expression was significantly decreased in PIA compared with NT $(p=.0007)$. Although NT and PC samples did not significantly differ, nuclear staining was observed in five of $10 \mathrm{PC}$ samples $(5 / 10)$ and one of four metastases.

E-cadherin membranous staining was observed in all normal epithelial prostatic cells (Fig. 2E), PIA and PC samples. E-cadherin expression differed significantly $(p<.007)$ among the groups. E-cadherin expression was decreased in PIA compared with the NT samples $(p=.001)$. All PC samples $(n=10)$ and two of four metastases showed that E-cadherin translocated from the membrane to the cytoplasm (Fig. 2F), and PC samples showed increased E-cadherin protein expression compared with PIA $(p=.008)$. NT and PC samples did not significantly differ.

Normal epithelial cells from prostate tissues showed CAV-1 granular cytoplasmic staining (Fig. 2G). CAV-1 expression levels in PC (Fig. 2H) and metastases were significantly increased compared with normal and PIA samples $(p<.05)$. CAV-1 protein expression was also increased in metastatic samples compared with NT and PIA $(p<.05)$.

\subsection{Pyrosequencing methylation analysis}

Pyrosequencing analysis revealed that the APC gene promoter region was unmethylated in normal, PIA and PC samples.

\section{Discussion}

Here, we report that $\beta$-catenin and CAV-1 proteins are involved in prostatic carcinogenesis and metastasis in dogs, similar to that described in humans (Kim et al., 2012; Wang et al., 2015; Yang et al., 2012). CTNBB1, APC and CDH1 gene expression analysis showed no significant differences between lesions and no correlation in protein expression, but some factors can explain this difference. For example, only $40 \%$ of protein concentration variation can be explained by mRNA levels, and protein can be more stable and abundant than mRNA (Schwanhäusser et al., 2011; Vogel and Marcotte, 2012). In addition, fixation, paraffin embedding and storage reduces mRNA recovery and quality (Doleshal et al., 2008). mRNA fragmentation in formalin-fixed and paraffin-embedded samples increases with storage time and formalin can chemically modify mRNA (Cronin et al., 2004; Masuda et al., 1999).

Protein expression differed statistically among normal prostatic tissue, PIA, PC and metastases for $\beta$-catenin and E-cadherin.

Membranous $\beta$-catenin protein expression decreased in PIA samples compared with NT, and a diffuse cytoplasmic $\beta$-catenin pattern was observed in five PIAs, similar to that observed by Debelec-Butuner et al. (2014) in human pre-neoplastic lesions (PIA and PIN), with increased cytoplasmic protein demonstrating an important role in tumour progression. The $\beta$-catenin/cadherin complex at the cell membrane is stabilized by phosphorylation events that can dissociate this complex and transfer $\beta$-catenin to the cytoplasm (López-Knowles et al., 2010). $\beta$ catenin can be downregulated by proteasomal degradation in the cytoplasm, or stabilized, accumulated and facilitated in its nuclear translocation, activating transcription of genes involved in cell cycle control, apoptosis, migration and carcinogenesis (Kypta and Waxman, 2012; Pećina-Slaus, 2010; Roos et al., 2016). 
Cytoplasmic $\beta$-catenin was also observed in all PC and metastasis samples, and similar to reports in human counterparts (Verras and Sun, 2006), few samples (2 PC and one metastasis) showed $\beta$-catenin translocation to the nucleus. APC also contains nuclear export signals (NES) used to shuttle nuclear $\beta$-catenin and translocate it to the cytoplasm (Wang et al., 2015). Interestingly, five samples (4 PC and 1 metastasis) with nuclear APC expression had no nuclear $\beta$-catenin expression, suggesting APC's role in nucleo-cytoplasmic shuttling of $\beta$ catenin. Cytoplasmic APC binds to cytoplasmic $\beta$-catenin and can be degraded by the AXIN complex, preventing its translocation to the nucleus (Stamos and Weis, 2013). However, PC samples showed heterogeneous loss of cytoplasmic APC protein, which can alter cytoplasmic $\beta$-catenin degradation via proteasomes.

Loss of membranous E-cadherin expression in PC samples suggests a connected loss of membranous E-cadherin/ $\beta$-catenin in prostate cancer and metastasis, ensuring that $\beta$-catenin is available for nuclear translocation. Previous studies by our group found no cytoplasmic E-cadherin in PC samples, but we found areas of membranous staining loss in PC samples, which differed from normal prostate tissue (Rodrigues et al., 2013). In the present study, the canine PC group had more aggressive PC samples (mainly Gleason scores of 8-10), which may explain the difference in the results.

APC promoter methylation was not observed in our canine PC samples. This differs from human prostate cancer, which is reported to be frequently methylated (Kypta and Waxman, 2012). In addition, APC showed cytoplasmic expression in both PC and metastatic samples. Nuclear expression was observed in four PC samples, and all had cribriform as a single or mixed histological pattern. These findings corroborate APC's involvement in prostate carcinogenesis in dogs, but differ from human prostate carcinoma because the APC gene is hypermethylated in over $50 \%$ of PC cases, and consequently, low protein expression is related to human neoplastic cell development (Richiardi et al., 2009).

Both PC samples with nuclear $\beta$-catenin expression received high Gleason scores, and only samples with Gleason scores of 10 had membranous $\beta$-catenin loss and gained cytoplasmic and/or nuclear staining, similar to human data where membranous loss was found in high-grade Gleason tumours (Chen et al., 2004). In humans, only $20 \%$ of advanced prostate tumours are associated with nuclear $\beta$-catenin, similar to our findings (Valkenburg et al., 2014).

Membranous E-cadherin and $\beta$-catenin expression play important roles in cell-cell adhesion. Loss of expression is a prerequisite for neoplastic cell invasion and metastasis and has a central role in epithelialmesenchymal transitioning in canine prostate cancer (Fonseca-Alves et al., 2015; Schmalhofer et al., 2009). Lower membranous E-cadherin expression in PC samples was higher in solid pattern areas than in adjacent patterns such as cribriform and small acinar/ductal. Our findings are consistent with the hypothesis that loss of E-cadherin expression is a dynamic alteration during cell dedifferentiation, permitting tumour cells to migrate through stroma, vessels and other tissues (FonsecaAlves et al., 2015; Younis et al., 2007).

In dogs, E-cadherin is dynamically expressed during prostate cancer development, even in pre-neoplastic lesions, with loss of membranous expression compared with normal prostate and benign prostatic hyperplasia (Fonseca-Alves et al., 2013; Rodrigues et al., 2013). E-cadherin expression significantly differed among the groups, with increased protein expression in PC samples compared to PIA, similar to the findings of Fonseca-Alves et al. (2015), with a discrete increase in protein expression in prostate cancer.

In human prostate cancer, a cytoplasmic E-cadherin pattern due to uncoordinated protein production has been reported, likely because it is an inactivated protein (Liu et al., 2014). PIA samples showed loss of Ecadherin protein expression. This may occur because $\mathrm{CDH}-1$ (E- cadherin) is regulated by TGF- $\beta$, which decreases E-cadherin expression (Liu et al., 2014). TGF- $\beta$ is secreted by several immune cells in the tumour's microenvironment (Fuxe and Karlsson, 2012). PIA is an excellent example of inflammation contributing to the cancer process. In a previous study, we described TGF- $\beta$ upregulation in PIA, and based on that, we infer that TGF- $\beta$ overexpression may interfere with decreased E-cadherin expression (Rodrigues et al., 2010).

CAV-1 is a membrane protein generally considered as a tumour progression marker and a target for cancer therapy (Klein et al., 2015). CAV-1 gene and protein expression increased progressively in PC compared with normal prostate and PIA samples. This increased expression was not observed in metastases, possibly due to the small sample size. Immunohistochemistry revealed granular CAV-1 and PC cytoplasmic staining with lower Gleason scores (grade 6) and showed lower protein expression than in higher Gleason score PC. In humans, CAV-1 expression is positively correlated with high-grade Gleason scores, early recurrence time and therapeutic resistance (Karam et al., 2007; Kuo et al., 2012; Quest et al., 2013).

The major limitations of the present study were the small case number and the unpaired samples used in the immunohistochemistry, RT-qPCR and pyrosequencing. Further studies are needed to clarify whether these proteins are involved in canine prostate lesions. To our knowledge, this is the first report describing the involvement of $\beta$-catenin, APC, CAV-1 and E-cadherin in canine PC. As in human data, CAV1 expression levels in canine prostate cancer were associated with higher Gleason scores.

Supplementary data to this article can be found online at https:// doi.org/10.1016/j.rvsc.2018.03.004.

\section{Conflicts of interest}

None.

\section{Funding}

This study was supported by Conselho Nacional de Desenvolvimento Científico e Tecnológico (443884/2014-5 and 131323/2014-8) and Fundação de Amparo à Pesquisa do Estado de São Paulo (2012/16068-0).

\section{References}

Bjerke, G.A., Pietrzak, K., Melhuish, T.A., Frierson, H.F., Paschal, B.M., Wotton, D., 2014. Prostate cancer induced by loss of Apc is restrained by TGF $\beta$ signaling. PLoS One 9, e92800. http://dx.doi.org/10.1371/journal.pone.0092800.

Cancer Genome Atlas Research Network, 2015. The molecular taxonomy of primary prostate cancer. Cell 163, 1011-1025. http://dx.doi.org/10.1016/j.cell.2015.10.025.

Cervantes-Arias, A., Pang, L.Y., Argyle, D.J., 2013. Epithelial-mesenchymal transition as a fundamental mechanism underlying the cancer phenotype. Vet. Comp. Oncol. 11, 169-184. http://dx.doi.org/10.1111/j.1476-5829.2011.00313.x.

Chen, G., Shukeir, N., Potti, A., Sircar, K., Aprikian, A., Goltzman, D., Rabbani, S.A., 2004. Up-regulation of Wnt-1 and beta-catenin production in patients with advanced metastatic prostate carcinoma: potential pathogenetic and prognostic implications. Cancer 101, 1345-1356. http://dx.doi.org/10.1002/cncr.20518.

Ciccarese, C., Massari, F., Iacovelli, R., Fiorentino, M., Montironi, R., Di Nunno, V., Giunchi, F., Brunelli, M., Tortora, G., 2017. Prostate cancer heterogeneity: discovering novel molecular targets for therapy. Cancer Treat. Rev. 54, 68-73. http:// dx.doi.org/10.1016/j.ctrv.2017.02.001.

Cronin, M., Pho, M., Dutta, D., Stephans, J.C., Shak, S., Kiefer, M.C., Esteban, J.M., Baker, J.B., 2004. Measurement of gene expression in archival paraffin-embedded tissues. Am. J. Pathol. 164, 35-42. http://dx.doi.org/10.1016/S0002-9440(10)63093-3.

Da Silva, L., Fonseca-Alves, C.E., Thompson, J.J., Foster, R.A., Wood, G.A., Amorim, R.L., Coomber, B.L., 2017. Pilot assessment of vascular endothelial growth factor receptors and trafficking pathways in recurrent and metastatic canine subcutaneous mast cell tumours. Vet. Med. Sci. 3, 146-155. http://dx.doi.org/10.1002/vms3.66.

De Marzo, A.M., Marchi, V.L., Epstein, J.I., Nelson, W.G., 1999. Proliferative inflammatory atrophy of the prostate. Am. J. Pathol. 155, 1985-1992. http://dx.doi. org/10.1016/S0002-9440(10)65517-4.

Debelec-Butuner, B., Alapinar, C., Ertunc, N., Gonen-Korkmaz, C., Yörükoğlu, K., 
Korkmaz, K.S., 2014. TNF $\alpha$-mediated loss of $\beta$-catenin/E-cadherin association and subsequent increase in cell migration is partially restored by NKX3.1 expression in prostate cells. PLoS One 9, e109868. http://dx.doi.org/10.1371/journal.pone. 0109868.

Doleshal, M., Magotra, A.A., Choudhury, B., Cannon, B.D., Labourier, E., Szafranska, A.E., 2008. Evaluation and validation of total RNA extraction methods for microRNA expression analyses in formalin-fixed, paraffin-embedded tissues. J. Mol. Diagn. 10, 203-211. http://dx.doi.org/10.2353/jmoldx.2008.070153.

Eble, J.N., Sauter, G., Epstein, J.I., Sesterhenn, I.A. (Eds.), 2004. WHO Classification of Tumors: Pathology and Genetics of Tumors of the Urinary System and Male Genital Organs. IARC Press, Lyon, France.

Fonseca-Alves, C.E., Kobayashi, P.E., Palmieri, C., Laufer-Amorim, R., 2017. Investigation of c-KIT and Ki67 expression in normal, preneoplastic and neoplastic canine prostate. BMC Vet. Res. 13, 380. http://dx.doi.org/10.1186/s12917-017-1304-0.

Fonseca-Alves, C.E., Kobayashi, P.E., Rivera-Calderón, L.G., Laufer-Amorim, R., 2015. Evidence of epithelial-mesenchymal transition in canine prostate cancer metastasis. Res. Vet. Sci. 100, 176-181. http://dx.doi.org/10.1016/j.rvsc.2015.03.001.

Fonseca-Alves, C.E., Rodrigues, M.M.P., de Moura, V.M.B.D., Rogatto, S.R., LauferAmorim, R., 2013. Alterations of C-MYC, NKX3.1, and E-cadherin expression in canine prostate carcinogenesis. Microsc. Res. Tech. 76, 1250-1256. http://dx.doi.org/ 10.1002/jemt.22292.

Fu, P., Chen, F.-C., Pan, Q., Zhao, X., Zhao, C., Cho, W., Chen, H., 2017. The different functions and clinical significances of caveolin-1 in human adenocarcinoma and squamous cell carcinoma. Onco. Targets. Ther. 10, 819-835. http://dx.doi.org/10. 2147/OTT.S123912.

Fuxe, J., Karlsson, M.C.I., 2012. TGF- $\beta$-induced epithelial-mesenchymal transition: a link between cancer and inflammation. Semin. Cancer Biol. 22, 455-461. http://dx.doi. org/10.1016/j.semcancer.2012.05.004.

Galuschka, C., Proynova, R., Roth, B., Augustin, H.G., Müller-Decker, K., 2017. Models in translational oncology: a public resource database for preclinical cancer research. Cancer Res. 77, 2557-2563. http://dx.doi.org/10.1158/0008-5472.CAN-16-3099.

Henderson, B.R., 2000. Nuclear-cytoplasmic shuttling of APC regulates $\beta$-catenin subcellular localization and turnover. Nat. Cell Biol. 2, 653-660. http://dx.doi.org/10 $1038 / 35023605$.

Ittmann, M., Huang, J., Radaelli, E., Martin, P., Signoretti, S., Sullivan, R., Simons, B.W., Ward, J.M., Robinson, B.D., Chu, G.C., Loda, M., Thomas, G., Borowsky, A., Cardiff, R.D., 2013. Animal models of human prostate cancer: the consensus report of the New York meeting of the mouse models of human cancers consortium prostate pathology committee. Cancer Res. 73, 2718-2736. http://dx.doi.org/10.1158/00085472.CAN-12-4213.

Jaggi, M., Johansson, S.L., Baker, J.J., Smith, L.M., Galich, A., Balaji, K.C., 2005. Aberrant expression of E-cadherin and beta-catenin in human prostate cancer. Urol. Oncol. Semin. Orig. Investig. 23, 402-406. http://dx.doi.org/10.1016/j.urolonc.2005.03. 024.

Karam, J.A., Lotan, Y., Roehrborn, C.G., Ashfaq, R., Karakiewicz, P.I., Shariat, S.F., 2007. Caveolin-1 overexpression is associated with aggressive prostate cancer recurrence. Prostate 67, 614-622. http://dx.doi.org/10.1002/pros.20557.

Karantanos, T., Karanika, S., Wang, J., Yang, G., Dobashi, M., Park, S., Ren, C., Li, L., Basourakos, S.P., Hoang, A., Efstathiou, E., Wang, X., Troncoso, P., Titus, M., Broom, B., Kim, J., Corn, P.G., Logothetis, C.J., Thompson, T.C., 2016. Caveolin-1 regulates hormone resistance through lipid synthesis, creating novel therapeutic opportunities for castration-resistant prostate cancer. Oncotarget 7, 46321-46334. http://dx.doi. org/10.18632/oncotarget.10113.

Kim, H., He, Y., Yang, I., Zeng, Y., Kim, Y., Seo, Y.W., Murnane, M.J., Jung, C., Lee, J.H., Min, J.J., Kwon, D.D., Kim, K.K., Lu, Q., Kim, K., 2012. $\delta$-catenin promotes E-cadherin processing and activates $\beta$-catenin-mediated signaling: implications on human prostate cancer progression. Biochim. Biophys. Acta Mol. basis Dis. 1822, 509-521. http://dx.doi.org/10.1016/j.bbadis.2011.12.015.

Klein, D., Schmitz, T., Verhelst, V., Panic, A., Schenck, M., Reis, H., Drab, M., Sak, A., Herskind, C., Maier, P., Jendrossek, V., 2015. Endothelial caveolin-1 regulates the radiation response of epithelial prostate tumors. Oncogene 4, e148. http://dx.doi. org /10.1038/oncsis. 2015.9.

Kobayashi, M., Saito, A., Tanaka, Y., Michishita, M., Kobayashi, M., Irimajiri, M., Kaneda, T., Ochiai, K., Bonkobara, M., Takahashi, K., Hori, T., Kawakami, E., 2017. MicroRNA expression profiling in canine prostate cancer. J. Vet. Med. Sci. 79, 719-725. http:// dx.doi.org/10.1292/jvms.16-0279.

Kuo, S.-R., Tahir, S.A., Park, S., Thompson, T.C., Coffield, S., Frankel, A.E., Liu, J.-S., 2012. Anti-caveolin-1 antibodies as anti-prostate cancer therapeutics. Hybridoma 31, 77-86. http://dx.doi.org/10.1089/hyb.2011.0100.

Kypta, R.M., Waxman, J., 2012. Wnt/ $\beta$-catenin signalling in prostate cancer. Nat. Rev. Urol. 9, 418-428. http://dx.doi.org/10.1038/nrurol.2012.116.

Lean, F.Z.X., Kontos, S., Palmieri, C., 2014. Expression of $\beta$-catenin and mesenchymal markers in canine prostatic hyperplasia and carcinoma. J. Comp. Pathol. 150, 373-381. http://dx.doi.org/10.1016/j.jcpa.2013.12.008.

LeRoy, B.E., Northrup, N., 2009. Prostate cancer in dogs: comparative and clinical aspects. Vet. J. 180, 149-162. http://dx.doi.org/10.1016/j.tvjl.2008.07.012

Li, V.S.W., Ng, S.S., Boersema, P.J., Low, T.Y., Karthaus, W.R., Gerlach, J.P., Mohammed, S., Heck, A.J.R., Maurice, M.M., Mahmoudi, T., Clevers, H., 2012. Wnt signaling through inhibition of $\beta$-catenin degradation in an intact Axin1 complex. Cell 149, 1245-1256. http://dx.doi.org/10.1016/j.cell.2012.05.002.

Liu, G.-L., Yang, H.-J., Liu, T., Lin, Y.-Z., 2014. Expression and significance of E-cadherin, $\mathrm{N}$-cadherin, transforming growth factor- $\beta 1$ and twist in prostate cancer. Asian Pac J
Trop Med 7, 76-82. http://dx.doi.org/10.1016/S1995-7645(13)60196-0.

Livak, K.J., Schmittgen, T.D., 2001. Analysis of relative gene expression data using realtime quantitative PCR and the $2^{\wedge}(-\Delta \Delta \mathrm{CT})$ method. Methods $25,402-408$. http://dx. doi.org/10.1006/meth.2001.1262.

López-Knowles, E., Zardawi, S.J., McNeil, C.M., Millar, E.K. a, Crea, P., Musgrove, E. a, Sutherland, R.L., O'Toole, S. a, 2010. Cytoplasmic localization of beta-catenin is a marker of poor outcome in breast cancer patients. Cancer Epidemiol. Biomark. Prev. 19, 301-309. http://dx.doi.org/10.1158/1055-9965.EPI-09-0741.

Masuda, N., Ohnishi, T., Kawamoto, S., Monden, M., Okubo, K., 1999. Analysis of chemical modification of RNA from formalin-fixed samples and optimization of molecular biology applications for such samples. Nucleic Acids Res. 27, 4436-4443. http://dx.doi.org/10.1093/nar/27.22.4436.

Mathieu, R., Klatte, T., Lucca, I., Mbeutcha, A., Seitz, C., Karakiewicz, P.I., Fajkovic, H., Sun, M., Lotan, Y., Scherr, D.S., Montorsi, F., Briganti, A., Rouprêt, M., Margulis, V., Rink, M., Kluth, L.A., Rieken, M., Kenner, L., Susani, M., Robinson, B.D., Xylinas, E., Loidl, W., Shariat, S.F., 2016. Prognostic value of Caveolin-1 in patients treated with radical prostatectomy: a multicentric validation study. BJU Int. 118, 243-249. http://dx.doi.org/10.1111/bju.13224.

Palmieri, C., Grieco, V., 2015. Proposal of Gleason-like grading system of canine prostate carcinoma in veterinary pathology practice. Res. Vet. Sci. 103, 11-15. http://dx.doi. org/10.1016/j.rvsc. 2015.09.004.

Palmieri, C., Lean, F.Z., Akter, S.H., Romussi, S., Grieco, V., 2014. A retrospective analysis of 111 canine prostatic samples: histopathological findings and classification. Res. Vet. Sci. 97, 568-573. http://dx.doi.org/10.1016/j.rvsc.2014.11.006.

Pećina-Slaus, N., 2010. Wnt signal transduction pathway and apoptosis: a review. Cancer Cell Int. 10, 22. http://dx.doi.org/10.1186/1475-2867-10-22.

Poniah, P., Mohd Zain, S., Abdul Razack, A.H., Kuppusamy, S., Karuppayah, S., Sian Eng, H., Mohamed, Z., 2017. Genome-wide copy number analysis reveals candidate gene loci that confer susceptibility to high-grade prostate cancer. Urol. Oncol. Semin. Orig. Investig. 35, 545.e1-545.e11. http://dx.doi.org/10.1016/j.urolonc.2017.04.017.

Quest, A.F.G., Lobos-González, L., Nuñez, S., Sanhueza, C., Fernández, J.-G., Aguirre, A., Rodríguez, D., Leyton, L., Torres, V., 2013. The caveolin-1 connection to cell death and survival. Curr. Mol. Med. 13, 266-281. http://dx.doi.org/10.2174/ 1566524011313020004.

Richiardi, L., Fiano, V., Vizzini, L., De Marco, L., Delsedime, L., Akre, O., Tos, A.G., Merletti, F., 2009. Promoter methylation in APC, RUNX3, and GSTP1 and mortality in prostate cancer patients. J. Clin. Oncol. 27, 3161-3168. http://dx.doi.org/10. 1200/JCO.2008.18.2485.

Richiardi, L., Fiano, V., Grasso, C., Zugna, D., Delsedime, L., Gillio-Tos, A., Merletti, F., 2013. Methylation of APC and GSTP1 in non-neoplastic tissue adjacent to prostate tumour and mortality from prostate cancer. PLoS One 8, e68162. http://dx.doi.org/ 10.1371/journal.pone.0068162.

Rivera-Calderón, L.G., Fonseca-Alves, C.E., Kobayashi, P.E., Carvalho, M., Drigo, S.A., de Oliveira Vasconcelos, R., Laufer-Amorim, R., 2016. Alterations in PTEN, MDM2, TP53 and AR protein and gene expression are associated with canine prostate carcinogenesis. Res. Vet. Sci. 106, 56-61. http://dx.doi.org/10.1016/j.rvsc.2016.03. 008 .

Rodrigues, M.M.P., di Santis, G.W., de Moura, V.M.B.D., Amorim, R.L., 2010. COX-2 and TGF- $\beta$ expression in proliferative disorders of canine prostate. Brazilian J. Vet. Pathol. 3, 31-36.

Rodrigues, M.M.P., Rema, A., Gartner, M.F., Laufer-Amorim, R., 2013. Role of adhesion molecules and proliferation hyperplasic, pre neoplastic and neoplastic lesions in canine prostate. Pak. J. Biol. Sci. 16, 1324-1329. http://dx.doi.org/10.3923/pjbs.2013. 1324.1329.

Roos, J., Grösch, S., Werz, O., Schröder, P., Ziegler, S., Fulda, S., Paulus, P., Urbschat, A., Kühn, B., Maucher, I., Fettel, J., Vorup-Jensen, T., Piesche, M., Matrone, C., Steinhilber, D., Parnham, M.J., Maier, T.J., 2016. Regulation of tumorigenic Wnt signaling by cyclooxygenase-2, 5-lipoxygenase and their pharmacological inhibitors: a basis for novel drugs targeting cancer cells? Pharmacol. Ther. 157, 43-64. http:// dx.doi.org/10.1016/j.pharmthera.2015.11.001.

Schmalhofer, O., Brabletz, S., Brabletz, T., 2009. E-cadherin, $\beta$-catenin, and ZEB1 in malignant progression of cancer. Cancer Metastasis Rev. 28, 151-166. http://dx.doi. org/10.1007/s10555-008-9179-y.

Schwanhäusser, B., Busse, D., Li, N., Dittmar, G., Schuchhardt, J., Wolf, J., Chen, W., Selbach, M., 2011. Global quantification of mammalian gene expression control. Nature 473, 337-342. http://dx.doi.org/10.1038/nature10098.

Seo, W.I., Park, S., Gwak, J., Ju, B.G., Chung, J.Il, Kang, P.M., Oh, S., 2017. Wnt signaling promotes androgen-independent prostate cancer cell proliferation through up-regulation of the hippo pathway effector YAP. Biochem. Biophys. Res. Commun. 486, 1034-1039. http://dx.doi.org/10.1016/j.bbrc.2017.03.158.

Siegel, R.L., Miller, K.D., Jemal, A., 2017. Cancer statistics, 2017. CA Cancer J. Clin. 67, 7-30. http://dx.doi.org/10.3322/caac. 21387.

Stamos, J.L., Weis, W.I., 2013. The $\beta$-catenin destruction complex. Cold Spring Harb. Perspect. Biol. 5 (a007898-a007898). https://doi.org/10.1101/cshperspect. a007898.

Toledo, D.C., Faleiro, M.B.R., Rodrigues, M.M.P., Di Santis, G.W., Amorim, R.L., De Moura, V.M.B.D., 2010. Caracterização histomorfológica da atrofia inflamatória proliferativa na próstata canina. Ciência Rural 40, 1372-1377. http://dx.doi.org/10. 1590/S0103-84782010000600021.

Valkenburg, K.C., Yu, X., de Marzo, A.M., Spiering, T.J., Matusik, R.J., Williams, B.O., 2014. Activation of Wnt/ $\beta$-catenin signaling in a subpopulation of murine prostate luminal epithelial cells induces high grade prostate intraepithelial neoplasia. Prostate 
74, 1506-1520. http://dx.doi.org/10.1002/pros.22868.

Vandesompele, J., De Preter, K., Pattyn, F., Poppe, B., Van Roy, N., De Paepe, A. Speleman, F., 2002. Accurate normalization of real-time quantitative RT-PCR data by geometric averaging of multiple internal control genes. Genome Biol. 3. http://dx. doi.org/10.1186/gb-2002-3-7-research0034.

Verras, M., Sun, Z., 2006. Roles and regulation of Wnt signaling and beta-catenin in prostate cancer. Cancer Lett. 237, 22-32. http://dx.doi.org/10.1016/j.canlet.2005. 06.004.

Vogel, C., Marcotte, E.M., 2012. Insights into the regulation of protein abundance from proteomic and transcriptomic analyses. Nat. Rev. Genet. 13, 227-232. http://dx.doi. org/10.1038/nrg3185.

Wang, Y., Fan, C., Yu, J., Wang, X., 2015. APC methylation predicts biochemical recurrence of patients with prostate cancer: a meta-analysis. Int. J. Clin. Exp. Med. 8, 15575-15580.

Yang, G., Goltsov, a.a., Ren, C., Kurosaka, S., Edamura, K., Logothetis, R., DeMayo, F.J.,
Troncoso, P., Blando, J., DiGiovanni, J., Thompson, T.C., 2012. Caveolin-1 upregulation contributes to c-Myc-induced high-grade prostatic intraepithelial neoplasia and prostate cancer. Mol. Cancer Res. 10, 218-229. http://dx.doi.org/10.1158/15417786.MCR-11-0451.

Younis, L.K., El Sakka, H., Haque, I., 2007. The prognostic value of E-cadherin expression in breast cancer. Int. J. Health Sci. (Qassim). 1, 43-51.

Yu, X., Wang, Y., Jiang, M., Bierie, B., Roy-Burman, P., Shen, M.M., Taketo, M.M., Wills, M., Matusik, R.J., 2009. Activation of $\beta$-catenin in mouse prostate causes HGPIN and continuous prostate growth after castration. Prostate 69, 249-262. http://dx.doi.org/ $10.1002 /$ pros. 20877.

Zhang, K., Guo, Y., Wang, X., Zhao, H., Ji, Z., Cheng, C., Li, L., Fang, Y., Xu, D., Zhu, H.H., Gao, W.-Q., 2017. WNT/ $\beta$-catenin directs self-renewal symmetric cell division of hTERT high prostate cancer stem cells. Cancer Res. 77, 2534-2547. http://dx.doi. org/10.1158/0008-5472.CAN-16-1887. 